Research Article

\title{
Low birth weight and its risk factors in a rural area of South India
}

\author{
Avita Rose Johnson, Surekha A.*, Astrid Dias, Neena Chris William, Twinkle Agrawal
}

Department of Community Health, St John's Medical College, Bangalore, Karnataka, India

Received: 13 July 2015

Revised: 14 July 2015

Accepted: 26 July 2015

\author{
*Correspondence: \\ Dr. Surekha, \\ E-mail: surecommed87@gmail.com
}

Copyright: () the author(s), publisher and licensee Medip Academy. This is an open-access article distributed under the terms of the Creative Commons Attribution Non-Commercial License, which permits unrestricted non-commercial use, distribution, and reproduction in any medium, provided the original work is properly cited.

\begin{abstract}
Background: Birth weight is a reliable and sensitive predictor of a new-born's chances for survival, growth and longterm physical and psychosocial development. There are few studies done in rural South India documenting valuable data such as detailed maternal nutritional intakes and psychological factors, and linking them to LBW. The objective was to estimate the proportion of LBW in a maternity center, Snehalaya hospital, Solur, Ramnagar district, Karnataka and to assess the factors affecting birth weight.

Methods: We conducted a cross-sectional study in a maternity centre, Snehalaya, in Solur Village, Ramnagar District, Karnataka between September and November 2014. Consecutive sampling was used to recruit 144 patients and the questionnaire was then administered to them.

Results: Among the 144 women, the proportion of LBW was found to be $14.6 \%$ and the mean birth weight was $2.6 \pm$ $0.4 \mathrm{~kg}$. We also found a significant association of birth weight with per capita income, maternal pregnancy weight gain, number of antenatal visits, maternal education, tobacco consumption, and stress and egg consumption in diet. Multivariate analysis showed significant association of birth weight with maternal pregnancy weight gain, tobacco consumption and stress.

Conclusions: A greater number of the subjects were found to have access to the basic antenatal care measures such as nutrition, free iron supplements and regular antenatal check-ups and this has shown to have a positive effect on the birth weight in the study population. Though various factors have been already proven to be associated, psychological and nutritional factors have to be concentrated henceforth.
\end{abstract}

Keywords: Low birth weight, Associated factors, Dietary, Psychological

\section{INTRODUCTION}

Birth weight is a reliable and sensitive predictor of newborns' chances for survival, growth and long term physical and psychosocial development. ${ }^{1}$ Infants weighing lesser than 2500 grams are approximately 20 times more likely to die than other babies, and are closely associated with foetal and neonatal mortality and morbidity. Low birth weight (LBW) leads to inhibited growth and cognitive development ${ }^{2}$ and is also associated with chronic diseases later in life. ${ }^{3}$ Since birth weight has a strong correlation with infant survival, attention needs to be given to strategies that will reduce the proportion of infants born with LBW. ${ }^{4}$ There are a few longitudinal studies done in rural South India that have linked LBW to diet, antenatal care, environmental and socio demographic factors. Most studies are record based and retrospective, losing out on essential data like nutritional intake by dietary recall. The present study, among a population of antenatal mothers attending a rural hospital, seeks to address the lacunae in available literature, while documenting associated risk factors for LBW which can be prevented or corrected during pregnancy, thereby reducing the proportion of LBW. This study was done with the aim to estimate the proportion of LBW in a rural 
maternity hospital in Karnataka, and to document the factors associated with birth weight.

\section{METHODS}

A cross sectional study was undertaken in a maternity hospital in a rural area of Ramnagara District, Karnataka. All women who were admitted for delivery at this missionary hospital were invited to participate in this study. Those antenatal mothers who were seriously ill were excluded. A sample size of 143 was calculated using an expected proportion of $21 \%$ low birth weight. 5 Ethical approval for the study was obtained from the Institutional Ethics Committee. Data was collected between September and November 2014. Consecutive sampling was used to recruit 144 women who were admitted for delivery and who gave written informed consent. A questionnaire was administered to the subject, which included socio-demographic details, antenatal and psychological risk factors and detailed history of dietary habits during the course of pregnancy, including a 24 hour dietary recall. Delivery details and details of the newborn were then recorded after the delivery.

\section{Statistical analysis:}

The data was entered and coded in Microsoft Excel and analyzed using SPSS version 16 for proportions, frequencies and associations. Descriptive statistics were reported using frequencies and proportions. The Chisquare test and Pearson's correlation test were used to find associations between LBW and its various possible risk factors. A p value of less than 0.05 was considered as statistically significant.

\section{RESULTS}

Of the 144 study subjects, $134(93.1 \%)$ were in the age group of 20 - 30 years, the mean age being 22.94 years. Most of the women i.e. $97(67.4 \%)$ were from a rural area, $58(40.3 \%)$ came from three-generational families, $61(42.4 \%)$ had completed their high school education and $51(35.4 \%)$ subjects belonged to Class-IV of the modified BG Prasad socio-economic scale.

Table 1: Socio demographic details.

\begin{tabular}{|c|c|c|c|c|}
\hline Domain & & LBW (\%) & Normal BW (\%) & P value \\
\hline \multirow{3}{*}{ Age } & $<19$ years & $2(22.2)$ & $7(77.3)$ & \multirow{3}{*}{0.43} \\
\hline & 20-30 years & $64(47.7)$ & $70(52.3)$ & \\
\hline & $>30$ years & $0(0)$ & $1(1)$ & \\
\hline \multirow{6}{*}{ Educational status } & Uneducated & $2(100)$ & $0(0)$ & \multirow{6}{*}{$0.02^{*}$} \\
\hline & Primary school & $3(60)$ & $2(40)$ & \\
\hline & Middle school & $8(61.5)$ & $5(38.5)$ & \\
\hline & High school & $21(34.4)$ & $40(65.6)$ & \\
\hline & Higher secondary & $18(43.9)$ & $23(56.1)$ & \\
\hline & Graduation & $7(31.8)$ & $15(68.2)$ & \\
\hline \multirow{5}{*}{$\begin{array}{l}\text { BG Prasad Socio } \\
\text { economic status(Class) }\end{array}$} & I & $2(22.2)$ & $7(77.3)$ & \multirow{5}{*}{$0.00^{*}$} \\
\hline & II & $12(40)$ & $18(60)$ & \\
\hline & III & $12(50)$ & $12(50)$ & \\
\hline & IV & $30(58.8)$ & $21(41.2)$ & \\
\hline & $\mathrm{V}$ & $18(60)$ & $12(40)$ & \\
\hline \multirow{4}{*}{ Family type } & Nuclear & $22(64.7)$ & $12(35.3)$ & \multirow{4}{*}{0.34} \\
\hline & Joint & $27(54)$ & $23(46)$ & \\
\hline & Three generation & $32(55.1)$ & $26(44.9)$ & \\
\hline & Living alone & $1(50)$ & $1(50)$ & \\
\hline
\end{tabular}

Various antenatal factors, thought to have an effect on birth weight, were then assessed for in our study population. We found that, of the 144 subjects, 139 (96.5\%) reported having had at least 3 antenatal checkups during the pregnancy. $137(95.1 \%)$ of the subjects had received iron tablets for at least 100 days of the pregnancy while all 144 subjects reported that they had received 2 doses of Tetanus toxoid vaccination or the booster dose. $18(12.5 \%)$ of the women had previously delivered LBW babies while only $2(1.4 \%)$ of them had undergone previous preterm deliveries. 26 ( $18.1 \%)$ of the women had undergone at least one previous abortion and $52(36.1 \%)$ of them were anemic at some point in the present pregnancy (Table 2). Anemia was assessed based on the women's haemoglobin levels $(<11 \mathrm{gm}$. \%).

We then assessed for various personal factors in the study population. We found that, most women i.e. $127(88.2 \%)$ reported an adequate gain (at least $9 \mathrm{~kg}$ ) during the pregnancy. $123(85.4 \%)$ of the women reported having adequate sleep at night (at least 8 hours) and 71 (49.3\%) of them reported having adequate daytime rest (at least 2 hours). In our study population, only $4(2.8 \%)$ women 
reported tobacco use while $26(18.1 \%)$ of them reported history of passive smoking (Table 3).

We also assessed for psychological factors by documenting self-reported history of depression, stress and anxiety and found that, of the 144 women, 6 (4.2\%),
$36(25.0 \%)$, and $16(11.1 \%)$ reported having felt depressed, stressed or anxious at some point in the pregnancy (Table 4).

Table 2: Showing awareness about the management of dog bite case among the study population.

\begin{tabular}{|c|c|c|c|c|}
\hline \multicolumn{2}{|l|}{ Domain } & LBW (\%) & Normal BW (\%) & P value \\
\hline \multirow[t]{2}{*}{ Antenatal check ups } & $>4$ & $60(43.1)$ & $79(56.9)$ & \\
\hline & $<4$ & $3(60)$ & $2(40)$ & \\
\hline \multirow{2}{*}{$\begin{array}{l}\text { Total IFA consumption } \\
\text { during pregnancy }\end{array}$} & $>100$ tablets & $38(27.3)$ & 101(72.7) & \multirow{2}{*}{0.07} \\
\hline & $<100$ tablets & $3(60)$ & $2(40)$ & \\
\hline \multirow{2}{*}{$\begin{array}{l}2 \text { TT injections or } 1 \\
\text { Booster }\end{array}$} & Taken & $34(23.6)$ & $110(76.4)$ & \multirow{2}{*}{0.21} \\
\hline & Not taken & $0(0)$ & $0(0)$ & \\
\hline \multirow[t]{2}{*}{ Anemia } & Present & $32(61.5)$ & $20(38.5)$ & \multirow{2}{*}{0.06} \\
\hline & Absent & $42(45.6)$ & $50(54.4)$ & \\
\hline $\mathrm{H} / \mathrm{O}$ any current & Yes & $46(66.6)$ & $23(33.4)$ & \multirow{2}{*}{0.45} \\
\hline Infections & No & $30(40)$ & $45(60)$ & \\
\hline \multirow{2}{*}{$\mathrm{H} / \mathrm{O}$ previous $\mathrm{LBW}$} & No & $12(66.8)$ & $6(33.2)$ & \multirow{2}{*}{0.07} \\
\hline & Absent & $86(68.2)$ & $40(31.8)$ & \\
\hline \multirow[t]{2}{*}{$\mathrm{H} / \mathrm{O}$ previous abortions } & Yes & $20(41.6)$ & $28(58.4)$ & \multirow{2}{*}{0.07} \\
\hline & No & $66(68.7)$ & $30(31.3)$ & \\
\hline
\end{tabular}

Table 3: Personal Factors.

\begin{tabular}{|lllll|}
\hline Domain & & LBW (\%) & Normal B W (\%) & P value \\
\hline Sleep at night & $>8$ hours & $50(37.5)$ & $83(62.5)$ & 0.06 \\
& $<8$ hours & $11(52.3)$ & $10(47.7)$ & \multirow{2}{*}{0.45} \\
\hline \multirow{2}{*}{ Rest during day } & $>2$ hours & $21(29.5)$ & $50(70.5)$ & $30(41.1)$ \\
\hline \multirow{2}{*}{ Tobacco use } & $<2$ hours & $43(58.9)$ & $1(25)$ & \multirow{2}{*}{$0.01^{*}$} \\
& Present & $3(75)$ & $122(87.1)$ & \multirow{2}{*}{0.54} \\
\hline \multirow{2}{*}{ H/O Passive smoking } & Absent & $18(12.9)$ & $12(46.2)$ & \multirow{2}{*}{$0.02^{*}$} \\
\hline \multirow{2}{*}{ H/o adequate weight gain } & Present & $14(53.8)$ & $78(66.2)$ & \\
& Absent & $40(33.8)$ & $7(41.2)$ & \\
\hline
\end{tabular}

Table 4: Psychological Factors.

\begin{tabular}{|lllll|}
\hline Domain & & LBW $(\%)$ & Normal BW $(\%)$ & P value \\
\hline Depression & Present & $4(66.6)$ & $2(33.4)$ & 0.33 \\
& Absent & $38(27.5)$ & $100(72.5)$ & $0.04^{*}$ \\
\hline Stress & Present & $25(69.4)$ & $11(30.6)$ & $50(46.3)$ \\
& Absent & $58(53.7)$ & $11(68.8)$ & 0.34 \\
\hline Anxiety & Present & $5(31.2)$ & $64(50)$ & \\
& Absent & $64(50)$ & & \\
\end{tabular}


Most of the women i.e. $118(81.9 \%)$ reported consuming non-vegetarian diets. $84(58.3 \%)$ of the women reported consuming an increased quantity of food during the pregnancy, as compared to their pre-pregnancy intake, whereas $49(34 \%)$ reported the same quantity and 11 (7.6\%) of them reported consuming less quantities of food during the pregnancy. Importantly, most of these women i.e. $106(73.6 \%)$ reported receiving and consuming food provided from their local Anganwadis (Table 5).

We found the proportion of LBW in our study population to be $14.6 \%$ i.e. 21 out of 144 women. We then analysed for any statistically significant associations between birth weight and the various risk factors mentioned above. Association assessed through Chi square and Fischer's exact test
On bivariate analysis, birth weight was significantly associated with tobacco consumption $(\mathrm{p}=0.010)$ and egg consumption $(\mathrm{p}=0.002)$. Subjects with higher per capita incomes were found to have delivered babies with higher birth weights $(\mathrm{p}=0.010)$. The birth weights were also found to be higher in women who reported greater weight gains during the pregnancy $(\mathrm{p}=0.007)$. Women who had gone for more number of antenatal check-ups were found to have higher birth weight babies $(\mathrm{p}=0.010)$. We also found that the birth weight increased with increase in the total number of years of the mother's education ( $p=$ 0.012) (Table 6). Multivariate analysis showed significant association of birth weight with maternal pregnancy weight gain, tobacco consumption and stress

Table 5: Nutritional factors.

\begin{tabular}{|c|c|c|c|c|}
\hline Domain & & LBW (\%) & Normal BW (\%) & P value \\
\hline Diet & $\begin{array}{l}\text { Veg } \\
\text { Non veg }\end{array}$ & $\begin{array}{l}30(35.7) \\
19((31.6)\end{array}$ & $\begin{array}{l}54(64.3) \\
41(68.4)\end{array}$ & 0.23 \\
\hline $\begin{array}{l}\text { Amount of food consumed during pregnancy } \\
\text { as compared to pre-pregnant state }\end{array}$ & $\begin{array}{l}\text { More quantity } \\
\text { Same quantity }\end{array}$ & $\begin{array}{l}30(35.7) \\
19((31.6)\end{array}$ & $\begin{array}{l}54(64.3) \\
41(68.4)\end{array}$ & 0.23 \\
\hline Milk intake & $\begin{array}{l}>500 \mathrm{ml} \\
\leq 500 \mathrm{ml}\end{array}$ & $\begin{array}{l}24(44.4) \\
45(50)\end{array}$ & $\begin{array}{l}30(55.6) \\
45(50)\end{array}$ & 0.07 \\
\hline Protein powder intake & $\begin{array}{l}\text { Present } \\
\text { Absent }\end{array}$ & $\begin{array}{l}30(44.7) \\
40(51.9)\end{array}$ & $\begin{array}{l}37(55.3) \\
37(48.1)\end{array}$ & 0.43 \\
\hline Availing Anganwadi nutrition & $\begin{array}{l}\text { Present } \\
\text { Absent }\end{array}$ & $\begin{array}{l}86(81.1) \\
12(31.5)\end{array}$ & $\begin{array}{l}20(18.9) \\
26(68.5)\end{array}$ & 0.21 \\
\hline
\end{tabular}

Table 6: Associations with birth weight.

\begin{tabular}{|lll|}
\hline & Correlation coefficient & p Value \\
\hline Per capita income & 0.215 & 0.010 \\
\hline Weight gain & 0.226 & 0.007 \\
\hline No. of ANC visits & 0.215 & 0.010 \\
\hline Mother's education (in years) & 0.210 & 0.012 \\
\hline Egg consumption & 0.312 & 0.002 \\
\hline
\end{tabular}

Table 7: Associations with birth weight.

\begin{tabular}{|llll|}
\hline & \multicolumn{1}{c|}{ Mean \pm SD } & Normal BW \\
\hline Age (years) & LBW & $24.441( \pm 4.19)$ & 0.46 \\
\hline IFA consumption & $22.981( \pm 3.14)$ & 24.45 & 0.07 \\
\hline Mean Hb (gm. \%) & $58.625( \pm 2.55)$ & $89.57( \pm 2.00)$ & 0.52 \\
\hline Mean duration of sleep(hours) & $10.08( \pm 6.54)$ & $11.74( \pm 5.47)$ & 0.06 \\
\hline Mean duration of rest (hours) & $6.656( \pm 1.60)$ & $8.407( \pm 1.37)$ & 0.23 \\
\hline Mean milk consumption (ml) & $1.806( \pm 1.33)$ & $2.118( \pm 1.14)$ & 0.32 \\
\hline Mean egg consumption (per week) & $46.559( \pm 9.45)$ & $52.17( \pm 8.831)$ & $0.02^{*}$ \\
\hline Mean duration of availing anganwadi nutrition(months) & $2.822( \pm 4.32)$ & $6.599( \pm 1.74)$ & 0.44 \\
\hline
\end{tabular}




\section{DISCUSSION}

Low birth weight is defined as a birth weight of less than $2500 \mathrm{gms}$, irrespective of the gestational age. It is either the result of preterm birth $(<37$ weeks gestational age) or Small-for-gestational age (SGA). The World Health Organization has estimated that annually 24 million LBW infants are born globally. The prevalence of LBW infants is around $5 \%$ in many developed countries and it changes between $5-30 \%$ in underdeveloped or developing countries. $^{5-8}$ There are various maternal, placental and foetal risk factors for LBW. Some of the important maternal factors are anaemia, insufficient weight gain during pregnancy, low socio-economic status, high parity and shorter birth intervals. There are important consequences of LBW such as perinatal asphyxia, hypothermia, infections and jaundice, long-term consequences such as slow learning, delayed cognition and poor growth. ${ }^{9-12}$

A target birth weight of at least $2.5 \mathrm{~kg}$ for $90 \%$ of newborns was one of the 12 indicators used as a part of the Health for All movement. Since birth weight is mainly conditioned by the health and nutritional status of the mother, its prevalence also closely reflects the health status of mothers, in particular, and the community, in general.

The prevalence of low birth weight in the study population was $14.6 \%$ and the mean birth weight was $2.6 \pm 0.4 \mathrm{~kg}$. Majority of the studies done in rural areas of India had the very high magnitude of LBW. ${ }^{13-16}$ But, one study done in Ballabgarh had the prevalence rate of LBW as low as $8.8 \%$ and another study conducted in West Bengal as high as $31.3 \%$. In the studies conducted in rural areas the mean birth weight of newborn ranged between $2.6 \pm 0.5$ to $2.8 \pm 0.4 \mathrm{~kg} \cdot{ }^{13,16-18}$ Most of the hospital based studies had the prevalence rate of LBW more than $30 \%$ and the mean birth weight of new born ranged between $2.5 \pm 0.4$ to $2.8 \pm 0.4 \mathrm{~kg}$. ${ }^{19-21}$ According to National Family Health Survey-3, over one in five $(22 \%)$ babies born in India were of LBW. The proportion weighing less than $2.5 \mathrm{~kg}$ is slightly higher in rural areas $(23 \%)$ than in urban areas $(19 \%))^{22}$ In this study, we found the proportion of LBW to be $14.6 \%$. We also found statistically significant associations between birth weight and per capita income, maternal pregnancy weight gain, total number of antenatal visits and maternal years of education. A similar rural hospital-based study done in Vellore, India from 2005 to 2008 found the prevalence of LBW to be $11.81 \%$ without any significant associated factors, while another rural hospital-based study done in Gambia in 2008 found a prevalence of $10.5 \%$ and associations between hypertensive disorders, antepartum hemorrhage and LBW. In our study population, a greater number of the subjects were found to have access to the basic antenatal care measures such as nutrition provided by the Anganwadis, free iron supplements and regular antenatal checkups and this has shown to have a positive effect on the birth weight in the study population. Based on our findings, other measures such as health and nutritional education in rural areas, as well as, promotion of education of the girl child will also help improve he current situation.

\section{CONCLUSION}

The proportion of low birth weight was $14.6 \%$ in the study population in Snehalaya Hospital, Solur, Ramnagar district, Karnataka. In our study, we found a statistically significant association between birth weight and factors such as per Capita Income, maternal weight gain during pregnancy, no. of ANC visits and maternal education (in years), tobacco consumption and also nutritional factor like egg consumption and psychological factor like stress.

\section{Funding: No funding sources}

Conflict of interest: None declared

Ethical approval: Approved by institutional ethics committee

\section{REFERENCES}

1. Biswas R, Dasgupta A, Sinha RN, Chaudhuri RN. An epidemiological study of low birth weight newborns in the district of Puruliya, West Bengal. Ind Jour of Pub Heal. 2008;25(5):65-71.

2. Low Birth Weight; Country, regional and global estimates. New York; UNICEF.2004;1-9.

3. Barker DJ. Foetal and infant origins of diseases. London: BMJ Books; 1992.

4. Emel A, Sultan K, Pınar ÖG, Zeynel A, Ayfer A. The incidence of low birth weight in 5000 live born infants and the etiology of foetal risk factors. Marm Med Jour. 2006;19(2):46-51.

5. Wessel H, Cnattingius S, Bergstrom S, Dupret A, ReitmaierP. Maternal risk factors for preterm birth and low birth weight in Cape Verde. ActaObstetGynecol Scand. 1996;75:36-46.

6. Geary M, Rafferty G, Murphy JF. Comparison of live born and stillborn low birth weight and analysis of aetiological factors. Ir Med J. 1997;90:269-71.

7. Najmi R. Distribution of birth weights of hospital born Pakistani infant. JPMA J Pak Med Assoc. 2000;121-4.

8. Low Birth weight. A tabulation of available information. Maternal Health and Safe Motherhood Programme. World Health Organization and UNICEF, Genova. 1992;92.2.

9. Thornton JG. Editorial. Eur J Obstet GynecolReprod Biol. 2001;95:5.

10. Williams RL, Creasy RK, Cunningham GC, Hawes WE, Norris FD, Tashiro M. Foetal growth and perinatal viability in California. Obstet Gynecol. 1982;59(4):624-63.

11. UNDP: Infants with low birth weight. [http://hdrstats.undp.org/ indicators/67.html]. 
12. De Onis M, Blossner M, VillarJ. Levels and patterns of intrauterine growth retardation in developing countries. Eur J ClinNutr. 1998;52(1):5-15.

13. Sachar RK, Kaur N, Soni RK, Dhot R, Singh H. Energy Consumption during Pregnancy \& its relationship to Birth Weight- A Population based Study from Rural Punjab. Ind Jour of Com Med. 2000;25(4):166-9.

14. Rao T, Aggarwal AK, Kumar R. Dietary Intake in Third Trimester of Pregnancy and Prevalence of LBW: A Community-based Study in a Rural Area of Haryana. Ind Jour of Com Med. 2007;32(4):2726.

15. Radhakrishnan T, Thankappan KR, Vasan RS, Sarma PS. Socioeconomic and Demographic Factors Associated with Birth Weight: A Community Based Study in Kerala. IndPediat. 2000;37:872-6.

16. Negi KS, Kandpal SD, Kukreti M. Epidemiological Factors Affecting Low Birth Weight. JK Science. 2006;8(1):31-4.

17. Kapoor SK, Kumar G, Pandav CS, Anand K. Incidence of Low Birth Weight in Rural Ballabgarh, Haryana. IndPediat. 2001;38:271-5.
18. Biswas R, Dasgupta A, Sinha RN, Chaudhuri RN. An Epidemiological Study of Low Birth Weight New-borns in the District of Puruliya, West Bengal. Ind Jour of Pub Heal. 2008;52(2):65-71.

19. Ghate MM, Pratinidhi AB, Gupte AM. Effects of Maternal Nutritional Status on Birth Weight of the Baby. Jour of Obst. \& Gyn. of India. 2001;51(1):38-41.

20. Idris MZ, Gupta A, Mohan U, Srivastava AK, Das V. Maternal Health and Low Birth Weight among Institutional Deliveries. Ind Jour of Comm Med. 2000;25(4):156-60.

21. Joshi HS, Subba SH, Dabral SB, Dwivedi S, Kumar D, et al. Risk Factors Associated with Low Birth Weight in New-borns. Ind Jour of Comm Med. 2005;30(4):142-3.

22. International Institute for Population Sciences (IIPS) and Macro International. National Family Health Survey (NFHS -3).2005-2006.

Cite this article as: Johnson AR, Surekha A, Dias A, William NC, Agrawal T. Low birth weight and its risk factors in a rural area of South India. Int J Community Med Public Health 2015;2:339-44. 